\title{
Entrepreneurial Marketing Strategy of Micro, Small and Medium Enterprises in Pandemic Covid-19 Era
}

Submitted 02/03/21, $1^{\text {st }}$ revision 10/04/21, $2^{\text {nd }}$ revision 29/04/21, accepted 25/05/21

\author{
Ernani Hadiyati ${ }^{1}$, Ferdian Hendrasto ${ }^{2}$
}

\begin{abstract}
:
Purpose: The Indonesian economy's core strength comes from micro, small and medium enterprises (MSMEs). However, the impact of the Covid-19 pandemic causes problems for MSMEs, for example, decreased sales, difficulties in financial aspects, slow distribution of products, and raw materials shortage. The problems of MSME during the Covid-19 pandemic require entrepreneurs' readiness to survive and sustain their business. Entrepreneurial marketing is a suitable paradigm to be implemented by MSME entrepreneurs during the Covid-19 pandemic. The research objective is to determine the entrepreneurial marketing strategy plan for MSMEs during the Covid-19 pandemic.

Research Methods: The research informants were government officials of Industry and Trade, MSME, and academicians. The data analysis model used a SWOT analysis based on IFAS and EFAS assessments. The strategic plan was positioned on the SWOT matrix with the values of strength, weakness, opportunity, and threats.

Findings: The results show that the SWOT matrix's entrepreneurial marketing strategy plan is in the position of Quadrant one. The entrepreneurial marketing strategy that should be applied in the quadrant is to support an aggressive growth policy.

Practical Implications: This aggressive growth strategy focuses on using the company's strengths to take advantage of various business opportunities during the Covid -19 pandemic. Originality value: This study contributes to the survivability of MSMEs in Indonesia, especially during the Covid-19, and shows practitioners to harness the inner strength of their businesses and pursue proactive marketing policy.
\end{abstract}

Keywords: Strategy, entrepreneurial marketing, Covid-19, MSMEs.

JEL classification: L10, M310.

Paper Type: Research paper.

${ }^{1}$ Gajayana University - Indonesia, ernani_hadiyati@unigamalang.ac.id

${ }^{2}$ Gajayana University - Indonesia, ferdian.h@unigamalang.ac.id; 


\section{Introduction}

Micro, Small, and Medium Enterprises (MSMEs) have an essential role in Indonesian society's economy. The Indonesian government also considers the critical existence of MSME entrepreneurs. The government's attention to MSMEs manifests the government's support for the small people economy. At the end of December 2019, the Coronavirus began to spread from Wuhan, China, to other countries widely and rapidly, and on March 11, 2020, the World Health Organization - WHO (2020) declared a pandemic COVID-19.

Every crisis brings about challenges and threats to entrepreneurs and their organizations. This starts with changes in human behavior, natural disasters, or economic mechanisms (Doern et al., 2019). A response to this incident is that the government in every country carries out policies to reduce the Coronavirus's spread and save lives by maintaining social distancing, widespread lockdowns, restrictions of travel, movement, and meeting people (Grima et al., 2020; Khan et al., 2020). According to the Ministry of Cooperation and Small and Medium Enterprises, there were around 37,000 MSMEs that were very seriously affected by the Covid-19 pandemic, that 56 percent of them reported a decrease in sales, 22 percent reported problems in the aspect of financing, 15 percent reported problems with the distribution of goods, and 4 percent reported difficulty in obtaining raw materials. The government policy has a significant impact on the performance of micro, small and medium enterprises (MSME) (Doh and Kim, 2014).

The potential loss of the MSME sector in East Java could reach 100 percent. MSME sales, in general, dropped down by 70-100 percent. The declining sales turnover had affected the company's unstable cash flow. The Ministry of Finance shows that the COVID-19 pandemic has negative implications for the domestic economy, such as decreasing consumption and purchasing power, decreasing company performance, threats to the banking and financial sectors, and MSMEs (Pakpahan, 2020). Many aspects of private and public life must be changed online (Liguori and Winkler, 2020). Limited resources and few customers suggest that entrepreneurial marketing is more suitable for SMEs (Franco et al., 2014; Hendijani, Fard, and Seyyed Amiri, 2018). Entrepreneurial marketing is a very appropriate concept for SMEs to be used, and it is by such business having characteristics of straightforward unplanned business management and unclear division of tasks within the organization. In the concept of Entrepreneurial Marketing, entrepreneurs take informal nonlinear marketing actions to manage environmental uncertainty with simple creative tactics that can improve business performance (Alqahtani and Uslay, 2020; Astuti et al., 2018; Brockman et al., 2012; Hacioglu et al., 2012; Morris et al., 2002).

\section{Literature Review}

\subsection{Business Strategy Planning and SWOT Analysis}


A corporate organization must match the company's internal strengths and external forces (opportunities and threats) with a market. The company carefully observes competition, government regulations, inflation rates, economic conditions, consumers' needs, wants, and other factors that can be identified as opportunities and threats. This analysis is known as the SWOT analysis (Strength, Weaknesses, Opportunities, and Threats) (Lee et al., 2009; Rangkuti, 2013). SWOT is a tool to determine organizational goal planning (Helms and Nixon, 2010). SWOT research is focused on organizations in analyzing recommended strategic actions. SWOT analysis has been extended to companies and industries in one country to another.

Tenney and Marquis (2017) explain that SWOT is a construction model used as a tool to predict the success of businesses in SMEs (Tenney and Marquis, 2017). Chan (2011) explains that SWOT is an analytical model for developing a comprehensive business strategy (Chan, 2011). This is an effective way to collect and classify information, describe certain things, and generate strategic planning ideas for businesses. (Agarwal et al., 2012). SWOT-analysis helps businesses make the right strategy by examining internal and external factors in-depth, resulting in effective decisions and strategic corporate planning for the future. SWOT can be used to predict business planning, strategic planning, competitor evaluation, marketing, business and product development, and research reports (Hadiyati, 2017).

Moreover, it can also be used in decision-making situations in setting goals for nonprofit organizations, government organizations, and individuals. Maulina (2018) states that SWOT analyzes critical factors that can be used to develop strategic plans, including determining the vision and mission of corporate organizations, including SMEs, even though they have limited resources (Hadiyati and Lukiyanto, 2019; Maulina, 2018). SWOT stands for strengths, weaknesses, opportunities, and threats that have an essential role for the stability and productivity of a corporate organization (Osita et al., 2014).

\subsection{Entrepreneurial Marketing and SMEs}

Entrepreneurial marketing is a new paradigm that combines entrepreneurial and marketing principles and describes companies' marketing process that pursues opportunities with limited resources in the market under uncertain conditions. Entrepreneurial marketing is a process that allows companies to use marketing activities to act as entrepreneurs and take advantage of opportunities to gain and retain customer benefits through innovative approaches. EM construct consists of seven (7) dimensions, namely, taking advantage of business opportunities, proactive orientation, focuses on creativity and innovation (the ability to be creative and unique in finding new solutions or rules), risk management to exploit opportunities, optimal use of resources, customer intensity, value creation to build long-term relationships) (Morris et al., 2002). Entrepreneurial marketing is needed to address increasing uncertainty and limited resources and organizational orientation with seven underlying dimensions: proactive, opportunity focus, calculated risktaking, innovation, customer intensity, resource enhancement, and value creation. 
Entrepreneurial marketing is situational, unplanned, informal, entrepreneurs took non-linear marketing actions to manage environmental uncertainty by creative and unsophisticated tactics (Alqahtani and Uslay, 2020; Brockman et al., 2012).

\subsection{Entrepreneurial Marketing and the Covid-19 Pandemic Crisis}

According to the Ministry of Cooperatives and Small and Medium Enterprises, there were around 37,000 MSMEs that were very seriously affected, 56 percent of them reported a decrease in sales, 22 percent reported problems in the aspect of financing, 15 percent reported problems with the distribution of goods, and 4 percent reported difficulty of obtaining raw materials. In solving SME marketing problems, appropriate marketing methods and strategies are required. An approach currently emerging in the application of product marketing by small and medium enterprises is entrepreneurial marketing (Stokes, 2000). Entrepreneurial marketing is a conceptual approach that is more appropriate in terms of limited resources and problems that often occur among MSMEs (Stokes, 2000). The concept of entrepreneurial marketing is appropriate for SMEs because of the rapid rate of technological change and consumer tastes, which creates uncertain conditions that cause traditional marketing strategies and tactics to be ineffective (Hills et al., 2008; Sheth and Sisodia, 2015).

Entrepreneurial marketing was born from the practice of companies operating in uncertain conditions and emerged as an alternative to overcome the decline in the effectiveness of conventional marketing (Whalen et al., 2016). This argument agrees with Hills et al. (2008), which explains that SMEs tend to implement EM strategies when companies face a very dynamic business environment.

\subsection{Government Policies in the Covid 19 Pandemic Crisis Against MSMEs}

A crisis hit the MSME sector in Indonesia in 1998, which reduced economic conditions. The difference in the crisis 22 years ago showed that MSMEs helped save the national economy. This is because although many industries got fallen, the export of MSMEs increased by 350\%. The high US dollar exchange rate drove the increase in MSME exports in 1998. Thus, the export of MSMEs commodity furniture and local raw materials for marine and agricultural products has increased with the US dollar condition in a high position. The impact of the spreading COVID-19 pandemic on Indonesia's economy is currently more complex than the crises in 1997-1998 and 2008-2009. This is because the virus affects not only human lives but also almost all economic sectors. The crisis conditions due to COVID-19 were much more complex than the 2008-2009 and 1997-1998 crises because the causes of the crisis in that era could be identified. The 2008-2009 crisis, which only happened to be the financial crisis that did not threaten people's lives down to the real sector.

Furthermore, government and the Ministry of Cooperatives and Small and Medium Enterprises (UKM) strive to maintain the survival of MSMEs by planning and implementing programs and mitigation measures for the corona outbreak's impact on cooperatives and SMEs. In implementing the mitigation program for the covid 19 
impacts, the government instructs budget reallocation and refocusing of policies to provide economic incentives for MSME and informal sectors to continue to produce and have activities and do not terminate employment (PHK). A stimulus is expected to encourage the growth of competitive MSMEs and contribute to the national economy (Kukanja et al., 2020).

\subsection{Research Methods}

This research is a quantitative study that describes the condition of MSMEs. The study population was convection MSMEs in seven cities or districts in East Java Province. The chosen sample was 20 UMKM entrepreneurs. Primary data collection was done using a questionnaire with a Likert scale measuring instrument with a rating of 1 answer strongly disagrees; two answers disagree, three answers are neutral, four answers agree. The strength variable is the advantage of MSMEs in implementing the concept of entrepreneurial marketing in covid situations. The opportunity variable is a critical situation that benefits the MSME company's environment in the covid pandemic situation, for example, government policies and internal information technology. Weakness variables are limitations or lack of skills, abilities as entrepreneurs, finance, management skills, and limited knowledge of digital marketing skills that hinder company performance in covid situations.

Threat variables are essential situations that do not benefit MSME companies in the covid era, for example, the government regulations to minimize the transmission of covid, changes in public or market consumption patterns, market situations with digital marketing, the difficulty of finding materials from suppliers, situations that do not support distributing goods in a covid situation. Data were analyzed with SWOT. The SWOT analysis method is a tool to plan and analyze strategic actions in up-todate situations (Ravanavar, 2012). SWOT stands for strengths, weaknesses, opportunities, and threats (Oreski, 2012), a system or process that considers internal and external factors that affect organizational performance (Hatta et al., 2019). Strengths and weaknesses are internal to the organization, opportunities and threats refer to the context of the operating organization's environment (Collins-Kreiner and Wall, 2007). The applied tool to develop a business development strategy is the SWOT matrix consisting of EFAS analysis based on opportunities and obstacles and IFAS based on strengths and weaknesses (Rangkuti, 2013). There are four alternative strategies for business development based on SWOT analysis one is the S-O strategy. This strategy has very favorable conditions. Namely, the system has good strengths and opportunities. S-O strategy is developed based on its mindset, namely by making the most of all strengths and opportunities. The S-T Strategy system has strengths but faces a variety of threats. This strategy is developed using the strengths of the company to overcome threats. The W-O strategy system has promising opportunities, but is limited by internal weaknesses (Niinimäki, 2018).

\subsection{Research Results}


The IFAS and EFAS matrices are a series of calculations of various internal factors, including strengths and weaknesses and external factors covering opportunities and threats that affect the company's sustainability. In this analysis, the internal factors (strengths and weaknesses) each consists of 10 factors, and external factors (opportunities and threats) each consist of 7 factors.

The IFAS matrix considers the strengths and weaknesses, each of which includes ten factors, and is weighted with a scale based on the influence of its strategic position. The rating calculation results ranging from the very strong to the very weak will be used as the basis to calculate the score, namely the weight multiplied by the rating. For more details, IFAS calculations can be seen in Table 1.

Table 1. Determination of IFAS Matrix

\begin{tabular}{|c|c|c|c|c|}
\hline Nr. & Factor & $\begin{array}{l}\text { Weight } \\
\text { (W) }\end{array}$ & Rating & BxR \\
\hline$\overline{\mathbf{A}}$ & \multicolumn{4}{|l|}{ STRENGTH } \\
\hline 1 & $\begin{array}{l}\text { Attempt to use business opportunity in Covid era and New } \\
\text { Normal }\end{array}$ & 0.03 & 3 & 0.09 \\
\hline 2 & $\begin{array}{l}\text { Establish good relationship with customers in Covid era and } \\
\text { new normal }\end{array}$ & 0.12 & 4 & 0.48 \\
\hline 3 & Business Creativity in Covid era-new normal & 0.07 & 3 & 0.21 \\
\hline 4 & $\begin{array}{l}\text { Responsive (Proactive) towards changes in Covid era-new } \\
\text { normal }\end{array}$ & 0.05 & 3 & 0.15 \\
\hline 5 & $\begin{array}{l}\text { Strategy of diversified entrepreneurship, business in Covid } \\
\text { era-new normal }\end{array}$ & 0.09 & 4 & 0.36 \\
\hline 6 & Orientation of market need in Covid era-new normal & 0.08 & 4 & 0,32 \\
\hline 7 & Innovation with digitalized business in Covid era -new normal & 0.04 & 3 & 0.12 \\
\hline 8 & Attempt to get profit in Covid era-new normal & 0.02 & 2 & 0.04 \\
\hline \multirow{2}{*}{\multicolumn{4}{|c|}{$\begin{array}{ll}\text { Total S } \\
\text { B WEAKNESSES }\end{array}$}} & 1.77 \\
\hline & WEAKNESSES & & & \\
\hline 1 & $\begin{array}{l}\text { Low qualified human resources with digital marketing in } \\
\text { Covid era-new normal }\end{array}$ & 0.08 & 2 & 0.16 \\
\hline 2 & $\begin{array}{l}\text { Lack of understanding on government policy in MSMEs } \\
\text { empowerment in Covid situation and New Normal }\end{array}$ & 0.05 & 2 & 0.10 \\
\hline 3 & $\begin{array}{l}\text { Human resources' Lack of Skill in facing digitalized business } \\
\text { in Covid era and new normal }\end{array}$ & 0.08 & 1 & 0.08 \\
\hline 4 & $\begin{array}{l}\text { Weak cash flow position of companies in Covid era-new } \\
\text { normal }\end{array}$ & 0.10 & 1 & 0.10 \\
\hline 5 & Weak business management in Covid era -new normal & 0.05 & 2 & 0.10 \\
\hline 6 & $\begin{array}{l}\text { Little improvement of marketing link in Covid era -new } \\
\text { normal }\end{array}$ & 0.06 & 2 & 0.12 \\
\hline 7 & Little online marketing in Covid era -new normal & 0.03 & 2 & 0.06 \\
\hline \multirow[t]{4}{*}{8} & $\begin{array}{l}\text { Little use of government policy to empower MSMEs } \\
\text { according to local wisdom in Covid era -new normal }\end{array}$ & 0.05 & 2 & 0.10 \\
\hline & Total B & $\mathbf{1}$ & & \\
\hline & \multicolumn{3}{|l|}{ Total W } & $\mathbf{0 . 8 2 0}$ \\
\hline & \multicolumn{3}{|l|}{ Total S-Total $\mathrm{W}=1.770-0.820$} & 0.950 \\
\hline
\end{tabular}

Source: Processed Primary Data (2020). 
Table 1 shows that the strengths and weaknesses strategy factors' total weighting is 1 (one). The total strategy factor for strength consists of 10 factors from a score of 1.77, and a strategic factor for weakness consists of 10 factors from a score of 0.820 . The difference in the total score of strengths and weaknesses is $1,770-0,820=0.950(+)$.

The FFAS matrix considers the opportunity and threat factors, each of which includes seven strategic factors, and is given weight on a scale based on the influence of its strategic position. The calculation of the rating from very strong to very weak will be used as the basis for calculating the score, namely the weight multiplied by the rating. For more details, the EFAS calculation can be seen in Table 2.

Table 2. The Weighting of EFAS Matrix

\begin{tabular}{|c|c|c|c|c|}
\hline Nr. & Factor & Weight (W) & Rating & WxR \\
\hline $\mathbf{A}$ & \multicolumn{2}{|l|}{ OPPORTUNITY } & & \\
\hline 1 & $\begin{array}{l}\text { The government policy of giving stimulating capital to } \\
\text { MSME in covid - new normal era }\end{array}$ & 0.05 & 2 & 0.10 \\
\hline 2 & $\begin{array}{l}\text { Potential domestic market in the covid -new normal } \\
\text { era }\end{array}$ & 0.06 & 4 & 0.24 \\
\hline 3 & $\begin{array}{l}\text { The government policy to improve human resources } \\
\text { quality by coaching, training and mentoring in the } \\
\text { covid - new normal era }\end{array}$ & 0.10 & 4 & 0.40 \\
\hline 4 & $\begin{array}{l}\text { The government policy to restrict imported product in } \\
\text { the covid -new normal era }\end{array}$ & 0.08 & 4 & 0.32 \\
\hline 5 & $\begin{array}{l}\text { The government policy for MSME to develop } \\
\text { networking in the covid - new normal era }\end{array}$ & 0.09 & 4 & 0.36 \\
\hline 6 & Open online marketing & 0.05 & 4 & 0.20 \\
\hline 7 & $\begin{array}{l}\text { The government policy for MSME partnership in the } \\
\text { covid -new normal era }\end{array}$ & 0.07 & 4 & 0.280 \\
\hline \multicolumn{4}{|c|}{ Total S } & 1.900 \\
\hline \multicolumn{5}{|c|}{ THREATS } \\
\hline 1 & $\begin{array}{l}\text { Market competition of similar product in the covid - } \\
\text { new normal era. }\end{array}$ & 0.06 & 2 & 0.120 \\
\hline 2 & $\begin{array}{l}\text { Economic growth condition in the covid -new normal } \\
\text { era. }\end{array}$ & 0.07 & 2 & 0.14 \\
\hline 3 & Uncertain market situation in covid -new normal era & 0.09 & 1 & 0.09 \\
\hline 4 & $\begin{array}{l}\text { Changing social life pattern in fulfilling their needs in } \\
\text { the covid -new normal era }\end{array}$ & 0.07 & 2 & 0.14 \\
\hline 5 & $\begin{array}{l}\text { New comers in the market in the covid -new normal } \\
\text { era. }\end{array}$ & 0.06 & 2 & 0.12 \\
\hline 6 & Inflation condition in the covid -new normal era & 0.07 & 2 & 0.14 \\
\hline 7 & Social political condition in the Covid-New normal era & 0.08 & 2 & 0.160 \\
\hline & Total Weight & 1.00 & & \\
\hline & Total T & & & 0.910 \\
\hline & \multicolumn{3}{|l|}{ Total O-Total Threats $=1.900-0.910$} & 0.990 \\
\hline
\end{tabular}

Source: Processed Primary Data (2020). 
Table 2 shows that the opportunity strategy and threat factor's total weight is 1 (one). The total strategy factor for opportunity consists of 7 factors from a score of 1,900 , and a strategy factor for threats consists of 7 strategic factors from a score of 0.910 . The difference between the total opportunity and threats is $1.900-0.910=0.990(+)$.

\subsection{Grand Strategy Determination}

The determination of the grand strategy is a matching stage as a strategy formulation process. According to the results of calculations in tables 9 and 10, the IFAS and EFAS matrices show the total score of each factor with the following details, strength 1.770 , weakness 0.820 , opportunities 1,900 , threats 0.910 . The detailed calculation of these scores shows that the value of strength is greater than the value of weakness with a difference of $(+) 0.950$. The value of the opportunity is greater than the value of threats with a difference (+) 0.990. According to the IFAS and EFAS analysis results in the grand strategy matrix, it can be used to determine the organization's position by considering the point of contact between IFAS (+0.950) and EFAS $(+0.990)$, namely in quadrant 1 . For more details, the position of the grand strategy can be seen in Figure 1.

Figure 1. SWOT Analysis

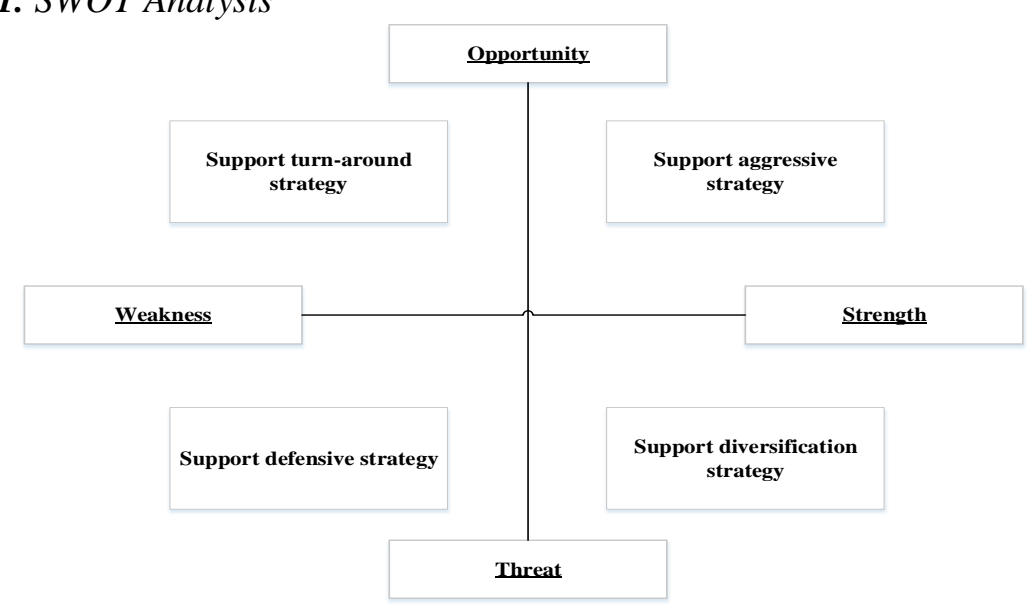

Source: Own creation.

In Figure 1, the IFAS and EFAS points of contact are in quadrant 1, which supports an aggressive strategy, namely creating a strategy with the strengths of the company that will be used to take advantage of business opportunities. The results of IFAS and EFAS calculations can be described in the Cartesian SWOT matrix diagram. The SWOT courtesies matrix diagram shows the significant position of the company's strategy in the Strategic Strength - Opportunity $(\mathrm{S}-\mathrm{O})$, the strategy is to create a strategy using the strengths they must take advantage of business opportunities. The determining of strategies in the new average Covid era by using the company's strengths include the ability to build relationships with customers, have business creativity, be proactive towards change, the orientation of growth and orientation to 
market needs to take advantage of government policy opportunities for the empowerment of MSMEs, the potential of the domestic market to improve human resources quality through coaching, training and mentoring, policies on limited import products to Indonesia, networking development, business partnerships.

\section{Discussion}

The analysis process with IFAS and EFAS is used to determine internal coordinate points, and the analysis of external coordinate points is used to determine quadrants and coordinate points on the SWOT matrix diagram. According to Figure 1, coordinate points are in strength and opportunities, which means that the entrepreneurial marketing strategy for convection MSMEs in East Java in the pandemic-new average era lies in Quadrant 1. The strategy that must be implemented in this condition is to support aggressive growth policies (growth-oriented strategy). The focus of this strategy is to use the company's strengths to take advantage of various opportunities. Convection MSMEs implement entrepreneurial marketing strategies. Aggressive strategy, namely using the company's strength to take full advantage of opportunities to be able to develop the convection MSME business in East Java. The IFAS and EFAS analysis results should carry out an SO strategy, namely a strategy that uses strength to take advantage of current opportunities, to determine the entrepreneurial strategy of convection MSMEs in East Java in the era of the expected covid-new pandemic.

For more details on the entrepreneurial marketing strategy for the convection MSMEs in East Java in the average covid-new era can be seen as follows:

Firstly, to take advantage of business opportunities supported by the government policy on limited imported products to enter Indonesia. Covid-19 pandemic provides an opportunity to improve the economy of Micro, Small, and Medium Enterprises (MSMEs) by increasing the consumption value of domestic MSME products and as one of the Indonesian savior's economy. The results of the production of MSMEs are used as substitute products for imported products. The government's policy of stopping imports of goods from abroad can be a driving force for developing MSME products to meet domestic market needs. According to the results of the FGD with the officials of the local office of trade, cooperative, and industry, it was explained that the socialization of the policy on the prohibition of imported products was carried out, and it urged MSMEs to be able to replace their products as substitute products for imported products. MSMEs entrepreneurs believe that they have not been optimal in taking advantage of these opportunities; there is a need for guidance and assistance for information related to these policies. MSMEs must utilize this government policy as a strategy for the survival and sustainability of MSMEs that contribute to Indonesia's economic growth.

Secondly, build relationships with customers by using online marketing. In the era of the new normal with a covid pandemic, the problem for MSMEs is marketing. The existence of government policies regarding restrictions on the community's 
movement and the number of employees working at home using the Work from Home (WFH) method has changed consumers' shopping behavior. There is a level of changing the consumer behavior offline to online (Schwarzl and Grabowska, 2015). With changes in consumer behavior, it is hoped that MSME entrepreneurs will immediately be proactive in the marketing strategies. MSME entrepreneurs maintain effective communication with customers to minimize problems or problems customers face with services from MSME companies. Communication with customers utilizes various information platforms through the website, email, social media, or messages in the application. Customers' interest in shopping online also directs MSME businesses to expand their business scope to the digital world with all the conveniences offered.

This approach is the right and effective way for companies to make customers stay afloat. In a new normal covid-19-pandemic situation, they must focus more and more on loyal customers who have made transactions with the company because the company's loyal customers have already trusted the company's products who understand the constraints and problems faced by the company. Companies carry out the customer loyalty strategy to communicate by taking advantage of advances in proliferating information technology.

The next step is conducting business creativity by utilizing empowerment policies to improve human resources quality through coaching, training, and mentoring. Business creativity in the era of the Covid 19 pandemic requires entrepreneurs who can come up with creative ideas following changing situations. MSME entrepreneurs should execute creative ideas as a strategy for business survival and sustainability. In providing support to MSME entrepreneurs, the government needs to streamline empowerment program policies to improve human resources quality through coaching, training, and mentoring. This is in line with the 2020-2024 RPJMN policy direction, namely strengthening business assistance institutions' capacity (incubators, training and mentoring centers). This government policy is more appropriate to be carried out in collaboration with related agencies, in this case, universities with human resources who are competent in their fields. The policy direction follows what was experienced by MSME entrepreneurs in the Covid-New era in doing business creativity, whether it is related to the products produced, this is a survival strategy for MSME entrepreneurs in uncertain situations.

Proactive towards business change by utilizing government policies in the MSME empowerment program is also a crucial step. In the new normal covid- era, entrepreneurs are more proactive about changes in uncertain situations. Entrepreneurs recognize changes in consumer behavior earlier. This will change the way of their business, for example, in interacting with customers. Proactive entrepreneurs will immediately map the patterns of consumer changing behavior, including their consumers' wants and needs, in the new normal covid-situation. For example, consumer and customer shopping behavior changes in the current situation by avoiding physical encounters. UMKM entrepreneurs must be proactive with consumer changing behavior by shopping online and utilizing information 
technology with the internet. Entrepreneurs must take advantage of the MSME empowerment program policies related to marketing through digital technology. According to information from the Ministry of Cooperatives and SMEs, it was stated that during the covid and new standard, MSME entrepreneurs in Indonesia who had problems with marketing through digital technology had reached 87\%. MSME entrepreneurs must quickly adapt to changing trends to develop appropriate marketing strategies. This includes the government's problems in realizing the policy direction of the 2020-2024 RPJMN, namely the use of digital technology to increase the added value and export of MSMEs.

Growth orientation by utilizing government policies for the MSME partnership program and building networking. Growth orientation is a corporate culture towards business growth which is the strength of the company. In the Covid pandemic and the new normal, company growth is a strength to take advantage of government policy opportunities to empower MSME partnership programs and develop networking. In synergy with a partnership based on mutual need, mutual trust, mutual support, and mutual benefit. The relationship must also uphold sound business ethics, carried out in a complete legal position. Relationships that take the form of transfer of expertise in production and processing, marketing, capital, human resources, and business management. According to Law Number 20 of 2008, Partnership patterns are concerned with Small and Medium Enterprises in the form of cooperation, plasma nucleus, sub-contracts, profit, general trade, distribution and agency, profit sharing, operational cooperation, joint ventures, outsourcing, other forms of partnerships.

Moreover, finally, the orientation of market needs by taking advantage of the openness of online marketing. The orientation of market needs is the corporate culture of MSMEs towards market needs as MSME companies' strength to take advantage of online marketing policies. Market need orientation includes customer orientation, competitor orientation, and orientation, and coordination between functions. Market orientation helps companies understand the market to take advantage of online marketing's openness in the Covid-new average era, namely the process of marketing products through internet media, which includes payments, promotions, and transactions via the web. MSME entrepreneurs can openly find out market needs by getting information from internet media. This strategy will help MSME companies to increase sales of their products.

\section{Conclusion}

The right strategy to use in the Covid-19 pandemic era is to support an aggressive strategy, namely an entrepreneurial marketing strategy using the company's strengths, including the ability to build relationships with customers, have business creativity, be proactive towards change, growth orientation, and orientation to market needs to take advantage of opportunities of the government empowerment policies for MSMEs: the potential of the domestic market to improve the quality of human resources through coaching, training and mentoring, policies on the limitation of imported products to Indonesia, networking development, business partnerships. 
Determining MSME entrepreneurial marketing strategy planning in the era of the Covid-19 pandemic can be seen as follows: take advantage of business opportunities by taking advantage of government policies regarding limited imported products entering Indonesia; the building of relationships with customers by utilizing online marketing; carrying out business creativity by utilizing empowerment policies to improve the quality of human resources through coaching, training and mentoring and policies to restrict imported products in Indonesia; proactive towards business changes by utilizing government policies in empowering MSMEs; growth orientation by utilizing government policies regarding MSME partnerships and networking development; rationalization of market needs by utilizing online marketing.

\section{References:}

Agarwal, R., Grassl, W., Pahl, J. 2012. Meta-SWOT: Introducing a new strategic planning tool. Journal of Business Strategy, 33(2), 12-21. https://doi.org/10.1108/02756661211206708.

Alqahtani, N., Uslay, C. 2020. Entrepreneurial marketing and firm performance: Synthesis and conceptual development. Journal of Business Research, 113, 62-71. https://doi.org/10.1016/j.jbusres.2018.12.035.

Astuti, R.D., Afiff, A.Z., Balqiah, T.E. 2018. Entrepreneurial marketing and marketing strategies of SMEs on marketing performance: An empirical analysis of fit. Pertanika Journal of Social Sciences and Humanities, 26, 39-53.

Brockman, B.K., Jones, M.A., Becherer, R.C. 2012. Customer Orientation and Performance in Small Firms: Examining the Moderating Influence of Risk-Taking, Innovativeness, and Opportunity Focus. Journal of Small Business Management, 50(3), 429-446. https://doi.org/10.1111/j.1540-627X.2012.00361.x.

Chan, X. 2011. A SWOT Study of the Development Strategy of Haier Group as One of the Most Successful Chinese Enterprises. International Journal of Business and Social Science, 2(11), 147-153.

Collins-Kreiner, N., Wall, G. 2007. Evaluating tourism potential: A SWOT analysis of the Western Negev, Israel. Tourism, 55(1), 51-63.

Doh, S., Kim, B. 2014. Government support for SME innovations in the regional industries: The case of government financial support program in South Korea. Research Policy, 43(9), 1557-1569. https://doi.org/10.1016/j.respol.2014.05.001.

Franco, M., Santos, M. de F., Ramalho, I., Nunes, C. 2014. An exploratory study of entrepreneurial marketing in SMEs: The role of the founder-entrepreneur. Journal of Small Business and Enterprise Development, 21(2), 265-283. https://doi.org/10.1108/JSBED-10-2012-0112.

Grima, S., Dalli Gonzi, R., Thalassinos, I.E. 2020. The Impact of COVID-19 on Malta and its Economy and Sustainable Strategies. Available at SSRN: https://ssrn.com/abstract=3644833.

Hacioglu, G., Eren, S.S., Eren, M.S., Celikkan, H. 2012. The Effect of Entrepreneurial Marketing on Firms' Innovative Performance in Turkish SMEs. Procedia - Social and Behavioral Sciences, 58, 871-878. https://doi.org/10.1016/j.sbspro.2012.09.1065.

Hadiyati, E. 2017. Model of MSME' s Competitiveness and Performance Excellent Product in Indonesia : an Approach of Government Policy. International Journal of Business and Social Science, 8(2), 99-108.

Hadiyati, E., Lukiyanto, K. 2019. The effect of entrepreneurial marketing dimensions on 
micro, small and medium enterprise performance in Indonesia. International Journal of Scientific and Technology Research, 8(10), 106-112.

Hatta, I.H., Riskarini, D., Ichwani, T. 2019. Business Development Strategy Model of SMEs Through SWOT and EFE-IFE Analysis. Shirkah: Journal of Economics and Business, 3(1). https://doi.org/10.22515/shirkah.v3i1.204.

Helms, M.M., Nixon, J. 2010. Exploring SWOT analysis - where are we now? A review of academic research from the last decade. Journal of Strategy and Management, 3(3), 215-251. https://doi.org/10.1108/17554251011064837.

Hendijani Fard, M., Seyyed Amiri, N. 2018. The effect of entrepreneurial marketing on halal food SMEs performance. Journal of Islamic Marketing, 9(3), 598-620. https://doi.org/10.1108/JIMA-12-2016-0097.

Hills, G.E., Hultman, C.M., Miles, M.P. 2008. The evolution and development of entrepreneurial marketing. Journal of Small Business Management, 46(1), 99112. https://doi.org/10.1111/j.1540-627X.2007.00234.x.

Khan, S., Rabbani, R.M., Thalassinos, I.E., Atif, M. 2020. Corona Virus Pandemic Paving Ways to Next Generation of Learning and Teaching: Futuristic Cloud Based Educational Model. Available at SSRN: https://ssrn.com/abstract=3669832.

Kukanja, M., Planinc, T., Sikošek, M. 2020. Crisis Management Practices in Tourism SMEs during the Covid-19 Pandemic. Organizacija, 53(4), 346-361. https://doi.org/10.2478/orga-2020-0023.

Lee, K.L., Huang, W.C., Teng, J.Y. 2009. Locating the competitive relation of global logistics hub using quantitative SWOT analytical method. Quality and Quantity, 43(1), 87-107. https://doi.org/10.1007/s11135-007-9087-1.

Liguori, E., Winkler, C. 2020. From Offline to Online: Challenges and Opportunities for Entrepreneurship Education Following the COVID-19 Pandemic. Entrepreneurship Education and Pedagogy, 3(4), 346-351. https://doi.org/10.1177/2515127420916738.

Maulina, E. 2018. SWOT Analysis for Business Strategies : A Case of Virage Awi in the Bamboo Craft Industries, Bandung, Indonesia. Review of Integrative Business and Economics Research, 7(2), 213-225. http://buscompress.com/journalhome.htm.

Morris, M.H., Schindehutte, M., LaForge, R.W. 2002. Entrepreneurial Marketing: A Construct for Integrating Emerging Entrepreneurship and Marketing Perspectives. Journal of Marketing Theory and Practice, 10(4), 1-19. https://doi.org/10.1080/10696679.2002.11501922.

Niinimäki, K. 2018. Sustainable Fashion in a Circular Economy. Sustainable Fashion in a Circular Economy, 12-42.

Oreski, D. 2012. Strategy development by using SWOT-AHP. TEM Journal, 1(4).

Osita, I., Onyebuchi, I., Nzekwe, J. 2014. Organization's stability and productivity: the role of SWOT analysis an acronym for strength, weakness, opportunities and threat. International Journal of Innovative and Applied Research, 2(9), 1-12. http://www.journalijiar.com.

Pakpahan, A.K. 2020. Covid-19 Dan Implikasi Bagi Usaha Mikro, Kecil, Dan Menengah. Jurnal Ilmiah Hubungan Internasional, 59-64. https://doi.org/10.26593/jihi.v0i0.3870.59-64.

Rangkuti, F. 2013. Teknik Membedah Kasus Bisnis Analisis SWOT Cara Perhitungan Bobot, Rating, dan OCAI. In PT. Gramedia Pustaka Utama. Jakarta. http://oaji.net/articles/2015/1937-1429848752.pdf.

Ravanavar, G.M. 2012. Strategic Formulation Using Tows Matrix - A Case Study. International Journal of Research and Development, 1(1), 8790. 
http://onlinelibrary.wiley.com/doi/10.1002/9780470713440.ch17/summary.

Schwarzl, S., Grabowska, M. 2015. Online marketing strategies: The future is here. Journal of International Studies, 8(2), 187-196. https://doi.org/10.14254/20718330.2015/8-2/16.

Sheth, J.N., Sisodia, R.S. 2015. Does marketing need reform?: Fresh perspectives on the future. In Does Marketing Need Reform? Fresh Perspectives on the Future. https://doi.org/10.4324/9781315705118.

Stokes, D. 2000. Putting Entrepreneurship into Marketing: The Processes of Entrepreneurial Marketing. Journal of Research in Marketing and Entrepreneurship, 2(1), 1-16. https://doi.org/10.1108/14715200080001536.

Tenney, D., Marquis, J. 2017. SWOT as a Constructive Predictor for Business Success of SMEs: A Case Study. Proceedings for the Northeast Region Decision Sciences Institute (NEDSI), 1014-1023.

http://search.ebscohost.com.aupac.lib.athabascau.ca/login.aspx?direct=true $\& \mathrm{db}=$ bth\&AN=122933205\&site=eds-live.

Whalen, P., Uslay, C., Pascal, V.J., Omura, G., McAuley, A., Kasouf, C.J., Jones, R., Hultman, C.M., Hills, G.E., Hansen, D.J., Gilmore, A., Giglierano, J., Eggers, F., Deacon, J. 2016. Anatomy of competitive advantage: towards a contingency theory of entrepreneurial marketing. Journal of Strategic Marketing, 24(1), 5-19. https://doi.org/10.1080/0965254X.2015.1035036. 